\title{
Imre Halász
}

\section{Changes in the Financial System of Vas County at the Beginning of the $20^{\text {th }}$ Century}

\begin{abstract}
The purpose of the study. To showcase the growth of the region's savings banks network during the period of Hungary's capitalist development between the turn of the century and the World War I.

Applied methods. Primarily data published in the financial almanac 'Magyar Compass' and newspaper articles of the time were sourced for the purposes of the study. Of financial indicators, balance sheet total and aggregate cash turnover figures were used. The study presents the accessible data of all the savings banks in operation at the time.

Outcomes. By the end of 1912, various types of financial services had already been available in 28 Vas County settlements with 53 savings banks operating in the county. Their number was augmented by five branches and two affiliates. The savings banks furthermore established 17 disbursement points. This network of financial institutions was complemented by the Austro-Hungarian Bank (Osztrák-Magyar Bank, OMB) and two discount houses operating in Szombathely. The market district of Szombathely covered the whole county. While several larger microregional money markets were created, significant amounts were repatriated by Hungarians emigrating to America. Amidst all these changes, two banks' bankruptcies made it known nationwide that the development of the local financial network was not without its failures.
\end{abstract}

Keywords: savings banks, Vas County, Szombathely, bank insolvencies, lines of business, AustroHungarian Bank

Until the turn of the century, within a little over two decades between 1878-1899, in the increasingly capitalist Vas County a nearly two-and-a-half-fold rise was seen in the number of financial institutions, a nearly eleven-fold growth in amount of initial capital, a 6.3-fold increase in the balance sheet total figures and a sharp rise in the aggregate cash turnover. Regional market centres got formed around the initial district seats. Similarly micro-regional money markets were created and transactions between the savings banks were picking up - the extent of which is unfortunately not corroborated by data. In 1897, 38 savings and 35 credit banks were actively offering their financial services to their customers. ${ }^{1}$

\section{The savings banks of the beginning of the century}

At the beginning of the $20^{\text {th }}$ century, a remarkable overview of the county's economy was provided by Gyula Éhen, a former mayor of Szombathely, which also covered financial institutions. In his study Éhen highlighted the fact that the circulation of goods had been increasing day by day in the former decades and that the ever modernised agriculture as the leading branch coupled with industrial location had provoked the development of debt instruments. Several financial institutions were formed, including the branches and disbursement points of savings banks. After the turn of the century, the business of Vas County financial institutions increased manyfold. The local economy was further bolstered by the establishment of a branch in Szombathely by the Austro-Hungarian Bank as one of their 33 branches, which meant that loan applications

Halász, I. (2021): 61-71. 
were directly reviewed in Szombathely so applicants could get the loans they had applied for in a much simpler way and in a shorter time than before. This branch had already realised the largest turnover among financial institutions in Vas County by 1905, so we can call it the engine for lending activities.

A high number of traders were among the customers of the Szombathely branch of the Austro-Hungarian Bank, who were granted loans at 3.5\% interest rates. The branch had significant Lombard lending activities too. ${ }^{2}$ Businesses (also) visited the branch of the AustroHungarian Bank since the locally founded savings banks, depending on their various lines of business, typically offered loans at double that rate, at 5-6\%. Éhen mentioned 707 trading companies over a half of which, 456 traders running their businesses at the county seat. The branch of the Austro-Hungarian Bank did not accept deposits; its total turnover amounted to $93,024,000$ Krones in $1904,{ }^{3}$ towering over the locally founded financial institutions. Of the other savings banks, operating as companies limited by shares, the outstanding total turnover of the Agricultural Savings and Credit Bank of 63,130,025 Krones was only two-thirds of that of the local branch of the Austro-Hungarian Bank and the former also handled deposits of 684,305 Krones. These two financial institutions were primarily active in investment and business financing operations.

The Austro-Hungarian Bank gradually expanded its network in the following decade; by 1912, it had been present in three Vas County settlements. Its branch in Szombathely started its operation as one of its 42 Hungarian branches in $1900^{4}$ already netting a turnover of 294,426,000 Krones in 1912. ${ }^{5}$ The credit review board of the Szombathely branch was predominantly made up of banking professionals, therefore Béla Borsics, the president of the Savings Bank of Szombathely, Gothard Sándor Herényi, the president of the Agricultural Savings and Credit Bank, Alajos Reiszig, the president of the General Savings Bank of Szombathely, Zsigmond Ungár, a board member of the Savings Bank of Szombathely Tradesmen as well as Lajos Kaiser, Gábor Legáth, Ede Müller, Sándor Pohl, István Sághy, Count sárvári és felsővidéki Rezső Széchenyi, Károly Weiner, Izsó Wolf were among the members of this expert panel. ${ }^{6}$

The branch operated two affiliates where no credit review board was in place and draft discounting services were offered by the savings bank under agreement with the AustroHungarian Bank: it was the Economic Credit Bank of Kemenesalja in Celldömölk and the Savings Bank of Szentgotthárd in Szentgotthárd. ${ }^{7}$

\section{Bank insolvencies}

The upward trend was overshadowed by two bank insolvencies that earned nation-wide notice and caused the demise of three Vas County and one metropolitan savings banks due to personal entanglements.

One involved the City Savings Bank of Szombathely and the highly reputable People's Bank of Vas-Zala, later called First Savings Bank of Vas-Zala, that had demonstrated intensive bank development from its beginnings and the other concerned the Savings Bank of Kiscell. The latter was caused by such a large scale of embezzlement which was even discussed by the conference for reforming savings banks held in Miskolc in 1899. The conference in Miskolc closely investigated the close relationships between financial institutions, industrial and commercial undertakings and excessive lending in order to identify the causes of insolvencies.

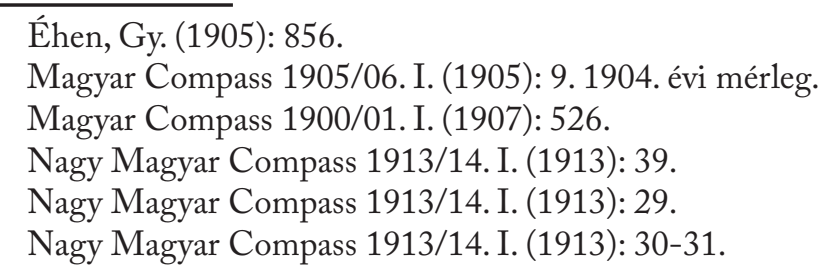


Besides similar instances in Arad, Máramarossziget, Érsekújvár and Újvidék, that of the Savings Bank of Kiscell was discussed in detail, all the more so, since the latter two cases had caused nationwide outcry. The collapse of the Savings Bank of Ujvidék was caused by a particularly high amount of loan granted to the Steam Mill of Ujjidék, whose assets had been lost by the general director at the stock exchange and which company consequently caused the savings bank to go bust too. Still, the Savings Bank of Kiscell, established in 1869, folded up as a result of persistent mismanagement: Lajos Rosenberg general director in collusion with accountant Károly Ritt had caused damage of about one million Krones to the financial institution over more than two decades. ${ }^{8}$

The Rosenberg family and relatives had been playing a determining role in the vicinity of Celldömölk and later in the whole county for several decades. The originally haberdasher and general dealer Rosenberg family of Kiscell and the related Pick family were closely related to the developers of the Hungarian West Railways and had shortly become exclusive suppliers to the railways construction works. Initially, for about two decades, they transported gravel at preferential rates, later conducted business in all kinds of goods even became involved in logging and the construction industry, and they eventually supplied everything from sleepers and rails to engines and cars while delivering gravel for national and county projects too.

By the time Rosenberg Jr. became the general director of the Savings Bank of Kiscell [today Celldömölk], the family had already grown into a determining player of economic and social life. Although there had been prior indications, and several people had even reported their findings demanding an investigation, nothing happened. After the scandal had broken out, the press made it clear that the Rosenberg family had been enjoying such vast respect and influence in the county that any fraud had been considered inconceivable. Still nothing happened when one of the depositors loudly demanded an explanation from the general director on the street claiming that the balance sheets had been doctored and finished this impromptu challenge by telling the director to feel free to report him for slander because in that case an investigation would finally be launched. Rosenberg stomached the affront and - nothing happened again. When the news of the arrest reached the settlement, depositors rightly worried about their savings besieged the savings bank where they were obviously not given any money just words of comfort that the directors' assets would cover the losses caused by the embezzlement.

Perceiving the signs of an imminent scandal, Rosenberg, his brother-in-law and some board members mortgaged any of their assets imaginable so that eventually no seizable assets remained and when the prosecutor's office finally motioned for the board members' assets to be attached, there was hardly any asset left to secure the deposits. The investigation quickly revealed that the accounts had been falsified and worthless bills of exchange had been placed in the savings bank. Ritt shortly made a confession admitting that they had been involved in such practices for approximately two and a half decades. Rosenberg and his brother-in-law Henrik Pick routinely took up large loans forgoing proper loan review procedures and covered up the embezzlement by falsifying the books of the savings bank. A significant part of the money was given to the accountant too. ${ }^{9}$ The investigating magistrate, among other things, presented an entry made on 13 February 1883 to the board members inquiring about their failure to notice the disbursements of 20,000 and 10,000 Krones without a loan review and approval or the deposit of a bill of exchange, to which the board members replied admitting their lack of related expertise. Today it is no longer possible to judge whether they really lacked expertise or it was simply their defence. People who were wise enough to rescue their money could hardly be accused of lacking expertise. ${ }^{10}$

Jirkovsky, S. (1942): 439-440.

A kis-celli panama. Alkotmány,1899. február 11.

10 Alkotmány, 1899. február 12. 4-5. 
After extensive investigations, the trial was started on 24 January 1902 at the Regional Court of Szombathely in the absence of the main culprit Lajos Rosenberg who promptly escaped and fled to the United States of America having been released from custody. Therefore chief accountant Ritt, accomplice Pick and further eleven members of the board of directors and of the supervisory board respectively were charged. At the end of a most rigorous hearing, the court sentenced Ritt to three years' imprisonment in a maximum security prison and banned from holding an office for six years, while the others were fined 100 Krones each. By then Rosenberg had already become a trader in majolica and porcelain ware in America ${ }^{11}$, so in his absence the proceedings were stayed against him until his arrest. ${ }^{12}$

Following prolonged negotiations, the financial problems could finally be settled by the four-fifth of the customers of the savings bank in Kiscell accepting the $60 \%$ settlement offered by the Agricultural Savings and Credit Bank of Szombathely. ${ }^{13}$ Although with significant losses, they recovered what could be recovered.

Shortly after the bankruptcy of the savings bank in Kiscell, further winding up procedures were seen caused by another subtle fraud to cleanse the financial market of Vas County.

The founder and first general director of the region's first modern financial institution, of the First Savings Bank of Vas-Zala, the highly reputed Ferenc Udvary born in 1840, who served as an MP for the Party of Independence and '48 for Körmend between 1887 and 1892, passed away at the age of 64 on 3 March 1904 . He was replaced by his son, born in 1868, an excellent athlete but less excellent politician and bank manager at the helms of the savings bank in Körmend. Udvary Jr., a slave to cycling gaining popularity at the time, was mostly wellrenowned with his younger brother for his ride from Körmend to the Paris World Fair in 1899 when they also visited Lajos Kossuth in Turin on their way home. ${ }^{14}$ Succeeding his father, the young man, a graduate from the Commercial Academy of Graz, directed the City Savings Bank of Szombathely besides the one in Körmend and even founded the People's Central Savings Bank in Budapest in 1904. Consequently, he managed to bankrupt three savings banks at the same time, and finally all three of them went into final dissolution as well as the one thousand golden Forint foundation of Udvary Sr., whose funds were handled by its own bank at the time, the First Savings Bank of Vas-Zala, and consequently the effect of the domino principle went beyond the scope of financial institutions. As evidenced by press reports, escaping liability, the savings bank would not even hear about the dissolution of the foundation, and the vice comes, in charge of ensuring legitimacy, handed over the case for investigation to the county prosecutor officer. $^{15}$

The first domino was the liquidity difficulties seen by the City Savings Bank of Szombathely. The crisis of the savings bank in Szombathely was indicated by not paying dividends for three years starting from 1901, although in 1904 they still managed to pay out 12 Krones by share. ${ }^{16}$ Still, operational difficulties were evident and - despite general anticipation - no solution was found. Udvary, running as a candidate of the Catholic People's Party and even elected MP for the Zirc district, established a savings bank in the capital city so that he could avoid failure by that bank's assets.

The City Savings Bank of Szombathely started to experience business difficulties in 1901, when the general director fell out with one of the board members, Károly Schmalz land owner from Styria, who wished to withdraw his deposit amounting to one and a half million Krones

11 Kis-Czell és vidéke 1902. február 9.3.

12 A kis-celli takarékpénztár. Alkotmány, 1902. január 25.11.

13 Pesti Napló 1899. augusztus 10.

14 Udvary, F. (1891).

15 Az Újság, 1907. április 23. 20. és Somogyi Hírlap, 1907. április 24. 3.

16 Magyar Compass 1905/06. I. (1905): 830. 
and offered all his shares for sale having resigned his board membership. Schmalz was unable to recover his money and forthwith petitioned for bankruptcy proceedings to be started against the savings bank in which he was joined by three other depositors, all from Graz. ${ }^{17}$

The investigations revealed a series of malpractices in no time while several more board members resigned saying that they did not identify with the savings bank's ethos.

Although the legal counsel for the savings bank had already proposed to petition for voluntary bankruptcy, Udvary would not hear of it, and rather chose to restore his tarnished reputation with the help of the savings bank established in the capital city. He invited wealthy representatives of his party and high priests to fund the bank, but when the subscriptions to the new bank's shares fell short of the expected amount, he himself invested large amounts taken out of the savings bank in Szombathely to purchase shares. He made this sum of money available by taking out a large loan against the one-million Krone estate of his brother-in-law, Béla Barthodeiszky in Beled, and deposited this amount with the savings bank in Szombathely. From then on, he managed the assets of the savings bank without any control; he entered into countless agreements claiming that the Barthodeiszky family would meet the arising obligations in the savings bank's stead. Therefore, along with the financial institutions, his wife's family was also forced to say farewell to their fortune: deposits of five hundred thousand Krones, cash of three hundred thousand Krones, his wife's dowry of one hundred and forty thousand Krones all disappeared; he also bankrupted his two brothers-in-law, who were board members of the savings bank in Szombathely. We may also count the notary public of Szombathely among his victims who committed suicide when facing financial ruins upon the downfall of the savings bank in Szombathely.

Later he took up a two-hundred-thousand Krone loan from Miklós Szemere, who, seeing his money getting lost, demanded the amount back. To gain time, Udvary handed over bonds to Szemere signed by two members of the boards of the financial institutions in Körmend and in Szombathely, respectively. The bankruptcy proceedings finally started in January $1907 .{ }^{18}$ The financial institutions went into liquidation and his wife's family also fell on hard times. ${ }^{19}$

Then Udvary disappeared. First, he lived in Bucharest under an assumed name but when he was revealed, he fled first to Constantinople, then to Smyrna (today: Izmir, Turkey), where he was eventually arrested on 20 March 1912. ${ }^{20}$ Exploiting the muddled Turkish domestic political scene of the time, he was not extradited; Udvary vanished for good.

As a result of personnel and capital entanglements the First Savings Bank of Vas-Zala, having been struggling with difficulties for about a decade, fell on hard times as well. The reason for the financial difficulties was the excessive bank branch network expansion. By 1906 it had already had four branches: in Németújvár, Szombathely, Zalaegerszeg and Kis-Czell. Then these branches were transformed into independent financial institutions in the form of companies limited by shares. Eventually, the bank's business operations covered more than twenty settlements. Through the acquisition of shares, the bank became part owner of the Savings Bank of Kemenesalja (1899), the City Savings Bank of Szombathely and of the Savings Bank of Zala County (1893) while participating in the foundation of the National Land Credit Institution for Small Landowners with 12,400 Krones and entering into an agreement with it on mediating mortgage bonds. It furthermore invested a significant amount of money in founding the Printing Works of Körmend. The new general director, due to the above-described machinations of the young Udvary, was unable to avoid liquidation. ${ }^{21}$

\footnotetext{
17 A szombathelyi városi takarékpénztár csődje. Pesti Hírlap, 1901. július 25. 10-11.

18 Magyar Compass 1907/08. I. (1907): 982.

19 Udvary Ferenc bankjai. Budapesti Hírlap, 1906. december 29. 5-6.

20 Elfogták Udvary Ferencet. Budapesti Hírlap, 1912. március 21. 10.

21 Magyar Compass 1907/08. I. (1907): 587-588. Felszámolás alatt.
} 


\section{Vas County savings banks at the beginning of the $20^{\text {th }}$ century}

According to Éhen's study, in 1904, the 39 financial institutions, including the branch of the Austro-Hungarian Bank, realised a turnover of 316,854,408 Krones in one year, of which the total value of deposits in the 38 financial institutions amounted to 52,089,620 Krones, indicative of people propensity to save up. The mayor, intent on economic and city development, described this fact as regrettable, since in his view, by using even this passive capital for city development further significant amounts of capital could have been funnelled into the economy. Although he was right as far as economic development is concerned, a significant part of this amount was the savings of natural persons, and therefore these amounts were (partly) primarily meant to assure the financial stability of the depositors - predominantly of deposit book holders. ${ }^{22}$

This picture is complemented by the incomes repatriated by emigrants. A significant part of such repatriated amounts was typically used to free estates from encumbrances in Pinkavölgy and the Szentgotthárd district. This was done in higher than average numbers in this region. Additionally, by then, the savings banks had already handled repatriated deposits in excess of one million Krones. It is primarily markedly represented in the balance sheet of the Savings Bank of Pinkafo" Township, where the annual total turnover amounted to 2,748,126 Krones with deposits of 2,147,212 Krones. But the ratio was similar at the Savings Bank of Pinkafó too, where against a 1,568,745 Krone annual turnover they handled deposits of 1,438,942 Krones. The situation may have been similar in Nagy-Német-Szentmihály (today: Grosspetersdorf) and Felsőőr; the former handled deposits of 1,155,127 against an annual turnover of 2,380,578, while the same figures at the Savings Bank of Felsőőr were 2,588,497 Krones against 6,825,734 Krones and we can see similar proportions albeit with lower amounts at the Savings Bank of the Felsőőr District, the other financial institution operating in the settlement. Éhen described these amounts as barren money and expressed his hope that returning emigrants would also invest these amounts in businesses. ${ }^{23}$

In the county 15 financial institutions and four bank branches got created during the less than one and a half decades between the turn of the century and World War I. This was the highest level of bank branch network expansion. The next level meant the creation of branches a number of which later evolved into independent savings banks with the founder holding a significant part of their shares. Following this pattern, the District People's Bank transformed into an independent joint stock company in Vasvár from the branch of the Savings Bank of Szentgotthárd in 1908 became involved in founding Járási Téglagyár rt., later called Első Vasvári Téglagyár. ${ }^{24}$

Creating branches was a conventional method of bank branch network expansion. Over time, the branches were transformed into individual companies limited by shares with the founders holding different proportions of shares. Such branches were established in Körmend in Celldömölk by the First Savings Bank of Vas-Zala, in Jánosháza by the Savings Bank of Kemenesalja, in Kisunyom, Csehimindszent and Gyepüfüzes by the Savings Bank of Pinkavölgy, in Köszeg by the Savings Bank of Szombathely and in Pusztaszentmihály and Strém by the Savings Bank of Németújvár.

It was of lesser significance for the savings banks to set up disbursement points or branches at a certain distance from their seats to accept deposits, grant small amount loans and cash coupons but not to offer full-scale financial services. The Savings Bank of Gyanafalva had a branch in Pusztaszentmihály and operated a disbursement point in Radafalva, the Credit Bank of Pinkafó Township did so in Alhó, the Savings Bank of Szentgotthárd in Felsőrönök, Kőszegszerdahely, Királyfalva, Némethidegkút, Rábakeresztúr, Vasdobra, Vasszentmihály, Vasvár and - the only

22 Éhen, Gy. (1905): 857.

23 Éhen, Gy. (1905): 856. A takarékpénztárak adatainak forrása: Magyar Compass 1905.

24 The company went under liquidation in 1935. Központi Értesítő, 1935. augusztus 8.568. 
acquisition reaching beyond the county limits - in Zalalövő, while the General Savings Bank of Szentgotthárd had a disbursement point in Radnafalva, Körtvélyes and Felsőszölnök and the Savings Bank of Hegyhát in Hosszúpereszteg.

The third method was affiliation; we are aware of four such cases in Vas County. In case of affiliated financial institutions, upon the share issue of an active savings bank, a certain part of the shares were purchased by more capital intensive savings banks thereby acquiring ownership. Such acquisition took place in 1910, when the Savings Bank of Szombathely acquired 400 shares of the nominal value of 100 Krones each in the Savings Bank of Hegyhát based in Vasvár. ${ }^{25}$ The president of the Savings Bank of Szombathely also became a board member, so the investment of the financial institution in Szombathely was directly controlled by him. A similar acquisition was transacted by the Savings Bank of Kemenesalja based in Celldömölk and the Savings Bank of Muraszombat. ${ }^{26}$ The ever closer relationship with the Savings Bank of Muraszombat started when the financial institution based in Szombathely established the Savings Bank of Muravidék in 1911 with the initial capital of 400 thousand Krones that did not prove viable and merged with the Savings Bank of Muraszombat on 21 July 1912. The financial institutions of Szombathely and Muraszombat formed a community of interest. ${ }^{27}$

The story of the Savings Bank of Kemenesalja is worth a mention, since it was originally a branch of the liquidated Körmend-based First Savings Bank of Vas-Zala that was later transformed into a company limited by shares and got affiliated by the Savings Bank of Szombathely. ${ }^{28}$ By doing so, they saved the savings bank, and the most capital intensive financial institution of the county did not only provide protection but also control.

The range of financial services was further expanded by the various savings banks entering into agreements with Budapest-based banks, which collaboration saved their customers the trouble of having to visit the seats of the respective savings banks to cash their coupons. This highlights the fact that a growing number of shareholders were Budapest residents.

Several financial institutions were members of the National Association of Financial Institutions (POE) founded in 1903, their association for interest representation, which is deemed to be the predecessor of the current Hungarian Banking Association. ${ }^{29}$ This interest representation organisation had 13 members in Vas County.

Certain insurance companies built up their network by entering into primary agency agreements with capital intensive savings banks. The Economic Credit Bank of Kemenesalja acted as primary agent for the First Hungarian General Insurance Company in Celldömölk, the Savings Bank of Szombathely was primary agent for the First Hungarian General Insurance Company in Vas County, and the West-Hungarian Economic Savings Bank was that of the Hungária General Insurance Company. Furthermore, the Vas County inspectorate of the General Insurance Company of Triest (Generali) was the Central Savings Bank of the County and its primary agent was the Savings Bank of Pinkavölgy in Monyorókerék. In total, four insurance institutions operated agencies in the county.

A further peculiarity is the presence of private banks on the money market. Magyar Compass mentioned two Szombathely-based private discount houses and bill discounting operations, one was the bill discounting and exchange business of the Grünwald brothers, where Ignác Feleki acted as its operator, and the company of Gusztáv Weisz. ${ }^{30}$

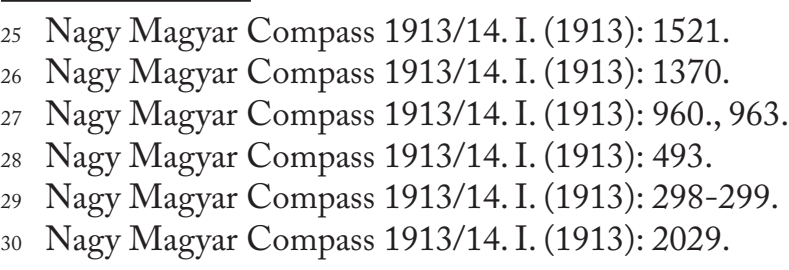




\section{On lines of business}

We can only enumerate the lines of business here. Even the smallest branches accepted deposits, handled bills and granted loans. The full portfolio was, however, only accessible in the savings banks with the largest markets. As for the placement of foreign capital, mortgage loans, savings deposits (predominantly in savings banks, there are high amounts in deposit books), certificates of deposit (extremely few), current account transactions, (mostly but not entirely in savings banks with higher cash turnovers) are the lines of business offered. The lines of business of active transactions include loans, bill portfolios, advancement against securities (except for private shares), pledges (unperishable goods, bullion and various valuables), overdraft facilities, mortgage loans (most frequent), loans (mortgage bond loans, mortgage credits), and promissory notes (almost entirely in credit banks, rarely in savings banks), property transactions and bonded warehousing; this latter is mostly available at institutions with an agricultural profile. Such a business - not elsewhere indicated - was transacted by the Celldömölk-based Economic Credit Bank, which had been involved in lending breeding heifers since 1903 with the intermediation of the Economic Association of Vas funded by the 80,000 Krone support of the Ministry of Agriculture.31

\section{Vas County financial institutions in 1913}

We can prepare the last accurate statement before WWI using balance sheet data as of 31 December 1912. Since the limitation on space does allow for a longer analysis to be given, we can only publish the main summary data here as follows,

\begin{tabular}{|c|c|c|c|c|c|}
\hline \multirow{3}{*}{$\begin{array}{l}\text { Settlement } \\
\text { [name used } \\
\text { after 1920] } \\
\text { number of } \\
\text { population }\end{array}$} & \multirow{3}{*}{$\begin{array}{l}\text { Name of finan- } \\
\text { cial institution } \\
\text { (foundation year } \\
\text { and planned term } \\
\text { of operation) }\end{array}$} & \multicolumn{2}{|c|}{$\begin{array}{l}\text { Balance sheet total } \\
\text { [of which govern- } \\
\text { ment securities] }\end{array}$} & \multirow[t]{3}{*}{$\begin{array}{c}\text { total tur- } \\
\text { nover }\end{array}$} & \multirow[t]{2}{*}{ Comments } \\
\hline & & 1911 & 1912 & & \\
\hline & & \multicolumn{2}{|r|}{ Krones } & & \\
\hline $\begin{array}{l}\text { Alhó } \\
\text { [Markt } \\
\text { Allhau, A] }\end{array}$ & $\begin{array}{l}\text { Alhói Takarékpénztár } \\
\text { (1913-1963) }\end{array}$ & n. a. & n. a. & n. a. & \\
\hline $\begin{array}{l}\text { Csehimind- } \\
\text { szent }\end{array}$ & $\begin{array}{l}\text { The branch of the } \\
\text { Savings Bank of } \\
\text { Pinkavölgy }\end{array}$ & n.a. & n. a. & n. a. & \\
\hline $\begin{array}{l}\text { Celdömölk } \\
\text { (Kiscell) } \\
5000\end{array}$ & $\begin{array}{l}\text { Kemenesaljai Takarék- } \\
\text { pénztár. } \\
(1890-1950) \\
\text { Evolved from the } \\
\text { defunct branch of } \\
\text { the First Savings } \\
\text { Bank of Vas-Zala }\end{array}$ & $1,613,171$ & $\begin{array}{r}1,841,689 \\
{[1,689]}\end{array}$ & $23,914,670$ & $\begin{array}{l}\text { é: Szombathelyi } \\
\text { Takarékpénztár }\end{array}$ \\
\hline
\end{tabular}

31 Nagy Magyar Compass 1913/14. I. (1913): 494. 


\begin{tabular}{|c|c|c|c|c|c|}
\hline & \begin{tabular}{|l} 
Kemenesajai \\
Közgazdasági \\
Hitelbank \\
$(1893-1943)$
\end{tabular} & $3,670,273$ & $\begin{array}{l}3,306,790 \\
{[100000]}\end{array}$ & $56,000,000$ & $\begin{array}{r}\text { POE, } \\
\text { OMB m. } \\
\text { r: Szentgáli } \\
\text { Takarékpénztár, } \\
\text { bf: Első Magyar } \\
\text { Általános } \\
\text { Biztosító, } \\
\text { m: Kemenesaljai } \\
\text { Önsegélyző } \\
\text { Szövetkezet }\end{array}$ \\
\hline \multirow[t]{3}{*}{\begin{tabular}{|l} 
Felsőőr \\
[Oberwart, A] \\
3410
\end{tabular}} & $\begin{array}{l}\text { Felsőőri Takarék- } \\
\text { pénztár } \\
(1872-1962) \\
\end{array}$ & $5,038,137$ & $5,381,845$ & $8,974,138$ & \\
\hline & $\begin{array}{l}\text { Felsőőri Járási } \\
\text { Takarékpénztár } \\
(1894-1924)\end{array}$ & 968,836 & $1,031,808$ & $2,752,772$ & \\
\hline & $\begin{array}{l}\text { Felsőőri Általános } \\
\text { Takarékpénztár } \\
(1894-1924)\end{array}$ & $\begin{array}{l}2,008,410 \\
{[288,000]}\end{array}$ & $\begin{array}{l}2,251,081 \\
{[281,800]}\end{array}$ & $4,555,711$ & \\
\hline $\begin{array}{l}\text { Felsőlendva } \\
\text { [Gornja } \\
\text { Lendava, SI] } \\
\end{array}$ & $\begin{array}{l}\text { Felsőlendvai } \\
\text { Takarékpénztár } \\
(1912-)\end{array}$ & n.a. & n.a. & n.a. & \\
\hline $\begin{array}{l}\text { Gyanafalva } \\
\text { [Jenners- } \\
\text { dorf, A] } \\
2166\end{array}$ & $\begin{array}{l}\text { Gyanafalvai } \\
\text { Takarékpénztár } \\
(1891-1921)\end{array}$ & $3,249,481$ & $3,639,638$ & $4,887,130$ & $\begin{array}{r}\text { fp: Puszta- } \\
\text { szentmihály, } \\
\text { fh: Radafalva }\end{array}$ \\
\hline \multirow[t]{2}{*}{$\begin{array}{l}\text { Jánosháza } \\
3457\end{array}$} & $\begin{array}{l}\text { Jánosházai } \\
\text { Takarékpénztár } \\
(1872-) \\
\end{array}$ & $\begin{array}{r}1,828,748 \\
{[54,300]}\end{array}$ & $\begin{array}{r}1,630,372 \\
{[50,640]}\end{array}$ & $5,601,258$ & \\
\hline & $\begin{array}{l}\text { Jánosháza-vidéki } \\
\text { Takarékpénztár } \\
\text { (1896-1926) } \\
\text { a: Kemenesaljai } \\
\text { Takarékpénztár } \\
\end{array}$ & $2,108,558$ & $2,088,068$ & n.a. & \\
\hline Kisunyom & \begin{tabular}{|l|} 
Sorokmelléki \\
Takarékpénztár \\
(1911-1961) \\
a: Pinkavölgyi \\
Takarékpénztár \\
\end{tabular} & 56,671 & 116,785 & n.a. & \\
\hline \multirow[t]{3}{*}{$\begin{array}{l}\text { Körmend } \\
5334\end{array}$} & $\begin{array}{l}\text { Körmendi Takarék- } \\
\text { pénztár (1871-1996) }\end{array}$ & $\begin{array}{r}4,890,464 \\
(1910) \\
{[158,375]} \\
(1911) \\
\end{array}$ & $\begin{array}{r}5,073,273 \\
(1911) \\
{[147,787]} \\
(1912) \\
\end{array}$ & $21,279,179$ & POE \\
\hline & $\begin{array}{l}\text { Körmendi Általános } \\
\text { Takarékpénztár } \\
(1895-1945) \\
\end{array}$ & 580,888 & 598,688 & $4,816,997$ & $\begin{array}{l}\text { KHK } \\
\text { POE }\end{array}$ \\
\hline & \begin{tabular}{|l|} 
Központi Takarék- \\
pénztár \\
$(1910-1940)$
\end{tabular} & $\begin{array}{r}722,705 \\
{[45,350]}\end{array}$ & $\begin{array}{r}968,970 \\
{[42,225]}\end{array}$ & $14,982,220$ & \\
\hline
\end{tabular}




\begin{tabular}{|c|c|c|c|c|c|}
\hline \multirow[t]{3}{*}{\begin{tabular}{|l|} 
Kőszeg \\
7076
\end{tabular}} & $\begin{array}{l}\text { Kőszegi Takarék- } \\
\text { pénztár (1844-1927) }\end{array}$ & $\begin{array}{r}12,077,178 \\
{[379,466]}\end{array}$ & $\begin{array}{r}12,292,313 \\
{[360,570]}\end{array}$ & $16,082,988$ & \\
\hline & $\begin{array}{l}\text { Kőszegi Általános } \\
\text { Takarékpénztár } \\
(1876-)\end{array}$ & $3,667,443$ & \begin{tabular}{r|}
$3,683,648$ \\
{$[85,170]$}
\end{tabular} & $10,947,438$ & \\
\hline & $\begin{array}{l}\text { Szombathelyi Takarék- } \\
\text { pénztár kőszegi } \\
\text { fiókja (1910-) }\end{array}$ & n.a. & n. a. & n.a. & \\
\hline 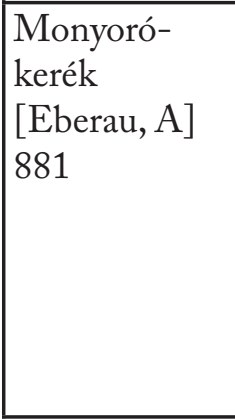 & $\begin{array}{l}\text { Pinkavölgyi } \\
\text { Takarékpénztár } \\
(1898-1948)\end{array}$ & $2,254,575$ & $2,473,911$ & $51,269,855$ & $\begin{array}{r}\text { POE } \\
\text { fh: Kisunyom, } \\
\text { Csehimindszent, } \\
\text { Gyepüfüzes, } \\
\text { r: Sorokmelléki } \\
\text { Takarékpénztár, } \\
\text { bf: Generali } \\
\text { megyei fö- } \\
\text { ügynöksége }\end{array}$ \\
\hline \multirow[t]{4}{*}{\begin{tabular}{|l} 
Muraszombat \\
[Murska \\
Sobota, SI) \\
2134
\end{tabular}} & $\begin{array}{l}\text { Muraszombati } \\
\text { Takarékpénztár } \\
\text { (1873-) } \\
\text { merged with the } \\
\text { Savings Bank of } \\
\text { Muravidék on } \\
\text { 21 July } 1912\end{array}$ & $3,834,970$ & $\begin{array}{r}5,263,562 \\
{[5,000]}\end{array}$ & $19,496,668$ & $\begin{array}{l}\text { é: Szombathelyi } \\
\text { Takarékpénztár, } \\
\text { r: Felsőlendvai } \\
\text { Takarékpénztár, } \\
\text { weekly deposit } \\
\text { insurance in } \\
\text { cooperation } \\
\text { with Universal }\end{array}$ \\
\hline & $\begin{array}{l}\text { Délvasmegyei } \\
\text { Takarékpénztár } \\
(1884-1950) \\
\end{array}$ & $1,744,827$ & $1,875,628$ & $22,193,996$ & POE \\
\hline & $\begin{array}{l}\text { Muraszombati } \\
\text { Mezőgazdasági } \\
\text { Bank (1898-1928) }\end{array}$ & $2,548,641$ & $\begin{array}{r}3,031,687 \\
{[42,225]}\end{array}$ & $26,716,312$ & $\begin{array}{r}\text { r: Szarvaslak- } \\
\text { vidéki, Péter- } \\
\text { hegyvidéki, } \\
\text { Vashidegkuti } \\
\text { Takarékpénztárak } \\
\end{array}$ \\
\hline & $\begin{array}{l}\text { Muravidéki } \\
\text { Takarékpénztár } \\
(1911-) \\
\text { a: The Savings Bank } \\
\text { of Szombathely } \\
\text { merged into the } \\
\text { Savings Bank of } \\
\text { Muraszombat in } 1912\end{array}$ & & & & \\
\hline \begin{tabular}{|l} 
Nagyszent- \\
mihály \\
[Grosspeters- \\
dorf, A] \\
2190 \\
\end{tabular} & $\begin{array}{l}\text { Nagyszentmihályi } \\
\text { Takarékpénztár } \\
(1872-1932)\end{array}$ & $\begin{array}{l}2,862,823 \\
{[136,500]}\end{array}$ & $\begin{array}{l}2,849,247 \\
{[131,625]}\end{array}$ & n.a. & \\
\hline \multirow[t]{2}{*}{$\begin{array}{l}\text { Németújvár } \\
\text { [Güssing, A] } \\
2008\end{array}$} & $\begin{array}{l}\text { Németújvári } \\
\text { Takarékpénztár } \\
(1872-)\end{array}$ & $\begin{array}{r}2,186,074 \\
{[27,150]}\end{array}$ & $\begin{array}{r}2,499,563 \\
{[25,335]}\end{array}$ & $24,960,403$ & $\begin{array}{l}\text { f: Pusztaszent- } \\
\text { mihály, Strém }\end{array}$ \\
\hline & $\begin{array}{l}\text { Németújvári Járási } \\
\text { Takarékpénztár } \\
(1901-)\end{array}$ & 167,125 & 173,144 & 262,720 & \\
\hline
\end{tabular}




\begin{tabular}{|c|c|c|c|c|c|}
\hline & $\begin{array}{l}\text { Németújvári Takarék- } \\
\text { és Hitelpénztár } \\
\text { (1894-1924) } \\
\text { a: Rába-Lapincs-völ- } \\
\text { gyi Takarékpénztár }\end{array}$ & $1,015,239$ & $1,009,705$ & $1,009,705$ & POE \\
\hline $\begin{array}{l}\text { Őriszentpéter } \\
1105\end{array}$ & $\begin{array}{l}\text { Orségi Takarékpénztár } \\
(1892-1922)\end{array}$ & $1,234,463$ & $1,349,827$ & $11,690,312$ & \\
\hline $\begin{array}{l}\text { Péterhegy } \\
\text { [Felső- } \\
\text { Petrócz, } \\
\text { Gornji } \\
\text { Petrovci, SI] }\end{array}$ & $\begin{array}{l}\text { Péterhegyvidéki } \\
\text { Takarékpénztár } \\
\text { (1907-1957) } \\
\text { a: Muraszombati } \\
\text { Mezőgazdasági Bank }\end{array}$ & 301,165 & 315,296 & $1,087,000$ & \\
\hline \multirow{2}{*}{$\begin{array}{l}\text { Pinkafő } \\
\text { [Pinkafend, A] } \\
2845\end{array}$} & $\begin{array}{l}\text { Pinkafóii Takarék- } \\
\text { pénztár (1870-) }\end{array}$ & $2,628,953$ & $2,775,619$ & $10,934,552$ & \\
\hline & $\begin{array}{l}\text { Pinkafói Községi } \\
\text { Hitelpénztár } \\
(1872-)\end{array}$ & $\begin{array}{r}4,598,104 \\
{[95,344]}\end{array}$ & $4,928,194$ & n.a. & fh: Alhó \\
\hline \multirow{2}{*}{$\begin{array}{l}\text { Pusztaszent- } \\
\text { mihály } \\
\text { [Sankt } \\
\text { Michael im } \\
\text { Burgenland, } \\
\text { A] } \\
1062\end{array}$} & $\begin{array}{l}\text { Gyanafalvai Takarék- } \\
\text { pénztár fiókpénztára }\end{array}$ & n.a. & n.a. & n.a. & \\
\hline & $\begin{array}{l}\text { Németújvári Takarék- } \\
\text { pénztár fiókja }\end{array}$ & n.a. & n. a. & n. a. & \\
\hline \multirow[t]{2}{*}{\begin{tabular}{|l} 
Rohonc \\
[Rechnitz, A] \\
3913
\end{tabular}} & $\begin{array}{l}\text { Rohonci Takarék- } \\
\text { pénztár } \\
(1873-)\end{array}$ & $\begin{array}{r}1,574,544 \\
{[16,000]}\end{array}$ & $\begin{array}{r}1,656,765 \\
{[16,000]}\end{array}$ & $4,732,653$ & \\
\hline & $\begin{array}{l}\text { Rohonci Általános } \\
\text { Takarékpénztár és } \\
\text { Önsegélyző Egylet } \\
\text { részvénytársaság } \\
(1910-1960)\end{array}$ & 111,008 & 162,738 & $1,157,634$ & \\
\hline \multirow[t]{2}{*}{$\begin{array}{l}\text { Sárvár } \\
2491\end{array}$} & $\begin{array}{l}\text { Sárvári Első } \\
\text { Takarékpénztár } \\
(1868-1899) \\
\end{array}$ & $\begin{array}{l}5,018,405 \\
{[409,818]}\end{array}$ & $\begin{array}{l}5,752,960 \\
{[374,664]}\end{array}$ & $77,807,340$ & \\
\hline & $\begin{array}{l}\text { Sárvár Vidéki } \\
\text { Takarékpénztár } \\
(1876-1906) \\
\end{array}$ & $1,775,820$ & $1,920,432$ & $10,499,905$ & \\
\hline $\begin{array}{l}\text { Strém } \\
{[\text { Strem, A] }}\end{array}$ & $\begin{array}{l}\text { Németújvári Takarék- } \\
\text { pénztár fiókja }\end{array}$ & n.a. & n. a. & n. a. & \\
\hline $\begin{array}{l}\text { Szarvaslak } \\
\text { [Rogasovci, } \\
\text { SI] }\end{array}$ & $\begin{array}{l}\text { Szarvaslakvidéki } \\
\text { Takarékpénztár } \\
\text { (1907-1957) } \\
\text { a: Muraszombati } \\
\text { Mezőgazdasági } \\
\text { Bank }\end{array}$ & 224,371 & 217,490 & n.a. & \\
\hline $\begin{array}{l}\text { Szentelek } \\
\text { [Stegersbach, } \\
\text { A] } \\
2958\end{array}$ & $\begin{array}{l}\text { Szenteleki Takarék- } \\
\text { pénztár } \\
(1891-1911)\end{array}$ & $\begin{array}{r}1,472,351 \\
{[26,064]}\end{array}$ & $\begin{array}{r}1,518,971 \\
{[24,321]}\end{array}$ & $9,021,701$ & $\begin{array}{r}\text { sz: Németújvári } \\
\text { Járási Takarék- } \\
\text { pénztár }\end{array}$ \\
\hline
\end{tabular}




\begin{tabular}{|c|c|c|c|c|c|}
\hline \multirow[t]{4}{*}{$\begin{array}{l}\text { Szentgotthárd } \\
2084\end{array}$} & $\begin{array}{l}\text { Szentgotthárdi } \\
\text { Takarékpénztár } \\
(1871-1901)\end{array}$ & $\begin{array}{r}9,073,733 \\
{[99,500]}\end{array}$ & $\begin{array}{r}9,949,947 \\
{[93,335]}\end{array}$ & $120,000,000$ & $\begin{array}{r}\text { POE } \\
\text { fh: Felsőrönök, } \\
\text { Kőszegszerda- } \\
\text { hely, Királyfalva, } \\
\text { Némethidegkút, } \\
\text { Rábakeresztúr, } \\
\text { Vasdobra, } \\
\text { Vasszentmihály, } \\
\text { Vasvár, Zalalövő. } \\
\text { Founded: } \\
\text { Járási Népbank } \\
\text { Vasvár, Zalalövői } \\
\text { Népbank, } \\
\text { sz: at the } \\
\text { institution, } \\
\text { Járási Népbank } \\
\text { Vasvár, Zalalövői } \\
\text { Népbank, } \\
\text { Budapesten: } \\
\text { Magyar Általános } \\
\text { Hitelbank }\end{array}$ \\
\hline & $\begin{array}{l}\text { Rába-Lapincs-völgyi } \\
\text { Takarékpénztár } \\
(1882-1942) \\
\end{array}$ & 815,764 & 767,976 & $1,553,009$ & $\begin{array}{r}\text { r: Németújvári } \\
\text { Takarék- és } \\
\text { Hitelpénztár } \\
\end{array}$ \\
\hline & $\begin{array}{l}\text { Szentgotthárdi Álta- } \\
\text { lános Takarékpénztár } \\
(1892-)\end{array}$ & $5,375,130$ & $4,761,747$ & n. a. & $\begin{array}{r}\text { fh: Radnafalva, } \\
\text { Körtvélyes, } \\
\text { Felsőszölnök } \\
\end{array}$ \\
\hline & \begin{tabular}{|l} 
Ipar- és Gazdasági \\
Népbank \\
$(1912-1962)$
\end{tabular} & n.a. & n. a. & n. a. & \\
\hline \multirow[t]{2}{*}{$\begin{array}{l}\text { Szombathely } \\
32000\end{array}$} & $\begin{array}{l}\text { Austro-Hungarian } \\
\text { Bank Szombathelyi } \\
\text { Fiókintézete } \\
\end{array}$ & n.a. & n. a. & $294,426,000$ & $\begin{array}{r}\text { OMB m: } \\
\text { Celldömölk és } \\
\text { Szentgotthárd }\end{array}$ \\
\hline & $\begin{array}{l}\text { Szombathelyi } \\
\text { Takarékpénztár } \\
\text { (1867-feloszlásig) }\end{array}$ & $23,000,671$ & $23,214,548$ & $618,106,369$ & $\begin{array}{r}\text { POE } \\
\text { f: Kőszeg, } \\
\text { é: Pesti Hazai } \\
\text { Első Takarék- } \\
\text { pénztár, } \\
\text { bf: Első Magyar } \\
\text { Általános } \\
\text { Biztosító megyei } \\
\text { föügynöksége, } \\
\text { af: Kemenesaljái } \\
\text { Takarékpénztár } \\
\text { Celldömölk, } \\
\text { Hegyháti } \\
\text { Takarék- } \\
\text { pénztár Vasvár, } \\
\text { Muraszombati } \\
\text { Takarékpénztár }\end{array}$ \\
\hline
\end{tabular}




\begin{tabular}{|c|c|c|c|c|c|}
\hline & $\begin{array}{l}\text { Szombathelyi } \\
\text { Általános Takarék- } \\
\text { pénztár } \\
(1873-1953) \\
\end{array}$ & $8,921,665$ & $9,282,324$ & $52,972,884$ & $\mathrm{POE}$ \\
\hline & $\begin{array}{l}\text { Vasmegyei Takarék- } \\
\text { pénztár } \\
(1885-1925)\end{array}$ & $\begin{array}{l}7,182,923 \\
{[579,238]}\end{array}$ & $\begin{array}{l}6,293,437 \\
{[537,701]}\end{array}$ & $171,158,288$ & $\mathrm{POE}$ \\
\hline & $\begin{array}{l}\text { Mezőgazdasági } \\
\text { Takarék- és Hitelbank } \\
(1897-1947)\end{array}$ & $\begin{array}{l}6,938,362 \\
{[529,869]}\end{array}$ & $\begin{array}{l}7,397,120 \\
{[461,488]}\end{array}$ & $299,473,358$ & $\begin{array}{r}\text { POE } \\
\text { é: Magyar } \\
\text { Általános } \\
\text { Hitelbank, } \\
\text { sz: at the } \\
\text { institution, } \\
\text { Budapesten: } \\
\text { Magyar Általános } \\
\text { Hitelbank }\end{array}$ \\
\hline & $\begin{array}{l}\text { Szombathelyi Iparosok } \\
\text { Takarékpénztára } \\
(1905-1955)\end{array}$ & $\begin{array}{r}1,621,760 \\
{[10,400]}\end{array}$ & $\begin{array}{r}1,718,702 \\
{[15,021]}\end{array}$ & $43,285,795$ & $\begin{array}{r}\text { m: penny- } \\
\text { association, } \\
\text { divided into } \\
\text { societies }\end{array}$ \\
\hline & $\begin{array}{l}\text { Nyugatmagyar- } \\
\text { országi Gazdasági } \\
\text { Takarékpénztár } \\
(1907-)\end{array}$ & $1,514,361$ & $1,287,577$ & $28,556,403$ & $\begin{array}{r}\text { POE } \\
\text { bf: Hungária } \\
\text { Általános } \\
\text { Biztosító } \\
\text { é: Belvárosi } \\
\text { Takarékpénztár } \\
\text { 1: községi hitel- } \\
\text { szövetkezet }\end{array}$ \\
\hline & $\begin{array}{l}\text { Vármegyei Központi } \\
\text { Takarékpénztár } \\
(1911-1961)\end{array}$ & $1,133,577$ & $\begin{array}{r}1,453,141 \\
{[8,808]}\end{array}$ & $31,873,515$ & $\begin{array}{r}\text { POE } \\
\text { bf: Trieszti } \\
\text { Általáno } \\
\text { Biztosítótársaság } \\
\text { (Generali) } \\
\text { Vas megyei } \\
\text { felügyelósége } \\
\end{array}$ \\
\hline & $\begin{array}{l}\text { Szombathelyi Egyház- } \\
\text { megyei Takarékpénztár } \\
\text { (1912-2002) }\end{array}$ & n.a. & n.a. & n.a. & \\
\hline & $\begin{array}{l}\text { The pawnshop of } \\
\text { Szombathely city }\end{array}$ & n.a. & n. a. & n.a. & \\
\hline \begin{tabular}{|l} 
Városszalónak \\
[Schlaining, \\
A] \\
1242 \\
\end{tabular} & $\begin{array}{l}\text { Városszalónaki } \\
\text { Takarékpénztár } \\
(1882-1914)\end{array}$ & $1,525,076$ & $\begin{array}{l}1,494,884 \\
{[376,481]}\end{array}$ & $2,762,532$ & \\
\hline
\end{tabular}




\begin{tabular}{|c|c|c|c|c|c|}
\hline \multirow[t]{3}{*}{$\begin{array}{l}\text { Vasvár } \\
3172\end{array}$} & $\begin{array}{l}\text { Hegyháti Takarék- } \\
\text { pénztár } \\
(1873-)\end{array}$ & $1,695,529$ & $1,632,106$ & $19,478,787$ & $\begin{array}{r}\text { POE } \\
\text { af: Szombathelyi } \\
\text { Takarékpénztár, } \\
\text { f: Hosszú- } \\
\text { pereszteg } \\
\end{array}$ \\
\hline & $\begin{array}{l}\text { Vasvári Takarékpénztár } \\
(1897-1927)\end{array}$ & $1,617,165$ & $1,917,294$ & $29,821,359$ & \\
\hline & $\begin{array}{l}\text { Járási Népbank } \\
\text { (1908-1938) } \\
\text { a: Szentgotthárdi } \\
\text { Takarékpénztár } \\
\text { fókpénztárából } \\
\end{array}$ & $1,750,284$ & $1,870,353$ & $31,917,333$ & $\begin{array}{r}\text { r: Járási Téglagyár } \\
\text { rt. (Later: } \\
\text { Első Vasvári } \\
\text { Téglagyár) }\end{array}$ \\
\hline $\begin{array}{l}\text { Vép } \\
2166\end{array}$ & $\begin{array}{l}\text { Vép és Vidéke } \\
\text { Takarékpénztár } \\
\text { (1896) }\end{array}$ & 670,886 & 737,411 & n. a & \\
\hline $\begin{array}{l}\text { Vashidegkút } \\
\text { [Cankova, SI] } \\
522\end{array}$ & $\begin{array}{l}\text { Vashidegkút-vidéki } \\
\text { Takarékpénztár } \\
\text { (1911-1961) } \\
\text { a: Muraszombati } \\
\text { Mezőgazdasági Bank } \\
\end{array}$ & 58989 & 84,886 & n. a & \\
\hline \multirow[t]{2}{*}{$\begin{array}{l}\text { Private } \\
\text { banks in } \\
\text { Szombathely }\end{array}$} & Ignác Feleki & n. a & n. a & n. a & $\begin{array}{r}\text { The bill } \\
\text { discounting and } \\
\text { exchange business } \\
\text { of the Grünwald } \\
\text { brothers. }\end{array}$ \\
\hline & Gusztáv Weisz & n.a. & n. a. & n.a. & \\
\hline
\end{tabular}

Source: Nagy Magyar Compass 1913/14. I. (1913).

Legend:

POE: member of the National Association of Financial Institutions

OMB m: an affiliate of the Austro-Hungarian Bank

a: founded by

af: affiliated to

bf: primary agency of an insurance company

é: in collaboration with

fh: disbursement point

fp: branch

1: established

m: operated

n.a.: n.a.

$\mathrm{r}$ : involved in

sz: cashing coupons

\section{The balance of the decade}

As of 31 December 1912, financial services were available in 28 settlements of the county in some form or other. 53 savings banks were in operation; 16 more than in $1899 .{ }^{32}$ This is a remarkable increase. The bank branch network was augmented by five branches and two affiliates and the savings banks also established a further 17 disbursement points. The network of the savings banks was further expanded by the operations of the Austro-Hungarian Bank and the two private

32 Conf. Halász, I. (2021): 67-68. 
discount houses operating in Szombathely. Savings banks were involved in creating further financial institutions eight times and provided their customers with five more coupon cashing opportunities in various financial institutions other than their own - also in the capital city.

The centre of the county money market was the county seat where eight companies limited by shares and two private financial institutions offered their services to their customers, and the city also had a pawnshop which counts among financial institutions by law. The market district of Szombathely covered the whole county and several larger microregional money markets were created with centres in Celldömölk, Kőszeg, Körmend,Muraszombat, Németújvár, Szentgotthárd and Vasvár. Magyar Compass documented a total annual turnover of 2,846,687,058 Krones (1912) of which 294,426,000 Krones were realised by the Szombathely branch of the AustroHungarian Bank, also includes the turnover figures of their two affiliates. Nine savings banks did not report annual turnover figures. Of this, excluding the figures of the Austro-Hungarian Bank branch, the turnover of the financial institutes operating in Szombathely amounted to $1,248,426,612$ Krones - approximately half the county figure - with the data of the freshly founded Diocesan Savings Bank of Szombathely unknown.

Vas County and the city of Szombathely saw robust expansion in the last one and a half decades of the 'Belle Époque'.

\section{Bibliography}

Bácskai Tamás (Ed.), A Magyar Nemzeti Bank története I. Budapest: Közgazdasági és Jogi Könyvkiadó Botos J. (1994), A magyarországi pénzintézetek együttmúködésének formái és keretei. Budapest: Közgazdasági és Jogi Könyvkiadó

Botos J. (2002), A magyarországi jelzálog-hitelezés másfél évszázada. Budapest: Szaktudás Kiadó Ház Éhen, Gy. (1905), Vas vármegye közgazdasági leirása. III. Közgazdasági Szemle 34. 853-863.

Halász, I. (2021), The Network of Financial Institutions and Capital Accumulation. Vas County in the Second Half of the 19th Century. in: Zoltán Kaposi, Virág Rab. (ed), Economic and Social Changes: Historical Facts, Analyses and Interpretations. Pécs. Studies on Economic and Social History from Southern Transdanubia I. 61-71

https://pea.lib.pte.hu/bitstream/handle/pea/23767/kaposi-rab-economic-and-social-changeswgeshrchasp-pecs-2021.pdf?sequence=3\&isAllowed=y (Letöltve: 2021 . december 1.)

Jirkovsky S. (1942), Takarékpénztáraink és a miskolczi 1899-es értekezlet. Közgazdasági Szemle, 85. 439-440. Kaposi, Z. (2002), Magyarország gazdaságtörténete. Budapest-Pécs: Dialóg Campus Kiadó

Tomka, B. (2000): A magyarországi pénzintézetek rövid története 1836-1947. Budapest: Aula

Udvary, F. (1891), Körmendtől-Párisig kerékpáron és vissza Turinnak. 2. ed. Körmend

Vargha Gy. (1896), A magyar hitelügy és hitelintézetek története. Budapest: Pesti Könyvnyomda-RészvényTársaság

\section{Sourcebooks}

Központi Értesítő, 1935. augusztus 8.

Magyar Compass (1900): Mihók-féle Magyar Compass 1900/01. I. rész: Pénz- és hitelintézetek. Galánthai Nagy Sándor (Ed.) Budapest

Magyar Compass (1905): Mihók-féle Magyar Compass 1905/06. I. rész: Pénz- és hitelintézetek. Galánthai Nagy Sándor (ed) Budapest

Magyar Compass (1907): Mihók-féle Magyar Compass 1907/08. I. rész: Pénz- és hitelintézetek. Galánthai Nagy Sándor (ed) Budapest

Nagy Magyar Compass 1913/14. I. (1913), Nagy Magyar Compass 1913/14. I. rész: Pénz- és hitelintézetek. Galánthai Nagy Sándor (Ed.). Budapest 